\title{
Exploration of Network Information Service Management of University Libraries under the Internet Background
}

\author{
Xiuhua Ma and Gemin Li \\ Jilin Agricultural University Library, Changchun 130118, China
}

Keywords: Internet age; University library; Network information service management

\begin{abstract}
People's living and working consumption habits have also been changed under the historical background of big data and Internet fast development. Network information services are also quietly changed in university libraries, wherein information management service scope and mode become more convenient. Service management ability and efficiency are improved through information technology management means, which has important role to develop university libraries. In the paper, corresponding reform measures and countermeasure suggestions are proposed in order to improve network information service level and efficiency in the university library through discussing network information service management characteristics of university library under the Internet background.
\end{abstract}

\section{Introduction}

Information technology permeates every field and plays a huge role with rapid development of modern technology. The university library also keeps up with the development of the times and constantly innovates in service management modes through modern information technology management means in the age of rapid development of modern information technology. Service management efficiency of university library is improved on the one hand, new channels are also increased for readers on the other hand, and thereby it has far-reaching significance for future development of university library. However, how to improve the quality of university library network information service management and maximally utilize Internet to provide convenience for more readers has become one of problems that should be studied and solved by university library in network information service and management with rapid development of computer technology and network communication technology in the face of the ever-changing high-tech environment at the same time.

\section{Analysis on Network Information Service Model of the University Library}

Service Scope of the Network Information of University Library. The scope is prominently increased compared with the management service scope of traditional university library in the knowledge service provided by the network information of the university library. Network is fully utilized for purchasing information with plan and focus in the aspect of network information services of university library. The collection is supplemented aiming at demand of reader users. Service function of e-reading room simply refers that multimedia technology is utilized for collecting, storing and accessing resources, information, documents, books, information and other contents, etc. Modern means of information technology is utilized for maximizing the function of library, thereby providing readers with vast amounts of electronic carriers.

Network Information Service Personnel in University Library. At present, the administrators of university library should have the ability of network information services. It is required that university libraries should be managed and maintained in the information network environment. Therefore, the university library should cultivate relevant professional talents, strengthen the management of talents, adapt to the needs of the era development, strengthen information service initiative of university library, and enhance the interaction and feedback information exchange with university library and readers. 
Network Information Service Mode of University Library. University library establishes network independent services under the support of information digital technology. Questions of all reader users can be answered by the management system, or problems which can not be solved by the system can be consulted online. The service mode also has multilingual question function. Readers users can search own desired information among many answers. The network information services of university library can be changed from original static services into active dynamic services.

\section{Network Information Service Characteristics of University Library in the Internet Age}

Diversified Network Information Carriers. The network information age creates new technology environment for collecting, sorting and developing university library information resources. It also greatly changes the form and quantity of collection literature resources in university library. The university library under network information management utilizes information technology for recording books, newspapers and other original literature into a database as data compared with traditional library. Reader users can read and use literature through establishing links by network or purchasing database, connecting mirror site, etc. University library can achieve massive dynamic information through network information technology, thereby greatly increasing the literature collection in university library and gradually forming a library with diversified information carrier.

Network-based Network Information Transfer. The information transfer mode in traditional university library is changed by the Internet age. In addition, it also changes the mode that readers must go to the university library for enjoying university library information services. The university library information services can be free from the limitation of time and space through the network-based service functions of information delivery, and it can become information service beyond time and space. Users can link university library network resources distributed all over the world. Literature information resources of university library can be utilized for breaking through single information service mode of traditional university library, thereby realizing network-based information delivery, and providing reader users with massive book information resources.

\section{Countermeasures and Suggestions of Improving Network Information Service Management in University Library in Internet Age.}

Optimization and sorting of Network Information of University Library. Reader users encounter a lot of information sources with complex contents and diversified categories during utilization of network resources in university library with updating of network technology and information technology means. It is difficult to search information in line with own demands immediately, thereby the information service efficiency of university library should be improved. University library should utilize the expertise of information service personnel in information retrieval and classification, and determine the standards of information collection and classification according to attribute of reader users, thereby network information resources can be organized, screened, integrated, optimized and stored in the library information servers. When reader users use retrieval data servers, they can search own desired information resources in the detailed categories. Meanwhile, new information services should be constantly developed in information service management of university library, and expand the social information service scope of university library, thereby providing the society with multi-level and multi-variety information services, and effectively improving the information service management level of university library.

Optimization of Network Information Retrieval Mode. Readers should search own information resources immediately, the sorted information sources should be optimized on the one hand, simple and convenient information retrieval mode is also required. Advantages of information resources should be fully exerted, the information retrieval mode also should be optimized and updated, vast information resources contents should be classified and judged accurately, and analyzed rationally. The optimization of retrieval mode also should adapt to the updating speed of network information. The retrieval mode should be optimized tightly aiming at user characteristics during organization, retrieval and processing of network information resources. When users use 
information retrieval function, dynamic browse and query of reader users should be monitored, thereby helping reader users to find the desired information resources most rapidly, and improving the efficiency of the university library network information services.

Improvement of Information Service Level in Multiple Modes. Firstly, network information resources construction of university library should be strengthened, university library should build websites by itself, strengthen the collection, organization, development and utilization of network information resources, and rich network information resources are converted into collection resources. The resources are digitally processed step by step, thereby forming website database. A variety of database and multimedia database are utilized for forming information resource database with rich resource. Secondly, the quality of librarians also should be improved in the Internet age, and the librarians also should take the initiative to shoulder the social information services. Network information service at higher level should be provided for users. The information resources are huge. Librarian should improve information, literature retrieval and other professional knowledge constantly, thereby enhancing the service ability of university library. Information technology should be utilized for deeply studying information demand characteristics and behavior characteristics of network users, thereby providing users with comprehensive and considerate information services actively and accurately.

\section{Conclusion}

The major trend of Internet big data development brings both opportunities and challenges to library service systems. University library is regarded as the center of information transmission, the library management personnel should make efforts to change the service idea and service mode, improve the service function of library constantly, broaden the scope of library service, and attach great importance to the training of innovative talents in the library in order to cope with the impact of the big data age, thereby integrating modern technology in the big data era into the service system of the library. Core competitiveness of library should be improved, thereby driving development of library service systems, and making contribution to comprehensive development of economy and society. Therefore, university library network information can be optimized and sorted, network information retrieval mode can be optimized to form large-scale information service websites, and information services can be provided for users better in order to improve the network information service efficiency and quality of university library.

\section{References}

[1] Li Mingli. Occupational right loss and regression path of university library in digital information age [J]. University Library Forum, 2014, 09: 1-8.

[2] Li Yunhong. Analysis on information service management mode of university library in the Internet age [J]. Heilongjiang Historical Annals, 2015, 3:2.

[3] Long Bin. How to carry out network information service of university library in the Internet age. [J]. Journal of Henna Academic Libraries, 2011.5:89-90.

[4] Xiong K,Perros H.Trust - based resouree alloeation in web serviees. Proeeedings of the International Conferenee on Web Serviees. Chieago, USA: IEEE Com Puter Society, 2006: 663

[5] J. N. Li, J. S. He. A User-Centric Model for Supporting Web Services. Proc. 2007 International Multi-Conference on Computing in the Global Information Technology, Gosier, Guadaloupe, 2007. IEEE Computer Society: 502 506.

[6] M.Aleksy, C. Atkinson, P. Bostan, et al. Interaction Styles for Service Discovery in Mobile Business Applications. Proc. 17th International Conference on Database and Expert Systems Applications, Kraków, Poland, 2006. Lecture Notes in Computer Science: 60 65.

[7] A. Eugene, B. Eric, D. Susan, et al.. Learning User Interaction Models for Predicting Web Search Result Preferences. Proc. 29th annual international ACM SIGIR conference on Research and development in information retrieval, Seattle, Washington, USA, 2006. ACM: 3 10.

[8] C.English, S.Terzis, P.Nixon. Towards Self-Protecting Ubiquitous Systems: Monitoring 
Trust-based Interactions. Personal and Ubiquitous Computing.2006, 10(1): 50 54. 